\title{
ANALISIS HUBUNGAN KEPEMIMPINAN EFEKTIF DAN KOMUNIKASI KEPEMIMPINAN DENGAN KEPUASAN PERAWAT DI RUANG RAWAT INAP RS
}

\author{
${ }^{1}$ Yeni Nur Rahmayanti, ${ }^{2}$ Christiana Arin Proborini, ${ }^{3}$ Nuriyah Yuliana \\ ${ }^{1}$ Sarajana Keperawatan, STIKes Mitra Husada Karangnyar, Email: yeninur2004@ gmail.com \\ ${ }^{2}$ Sarajana Keperawatan, STIKes Mitra Husada Karangnyar, Email: christianaarin123@yahoo.com \\ ${ }^{3}$ Sarajana Keperawatan, STIKes Mitra Husada Karangnyar, Email: nuriyah_yuliana@yahoo.com
}

\begin{abstract}
ABSTRAK
Kepuasan perawat di RSUD Karanganyar kurang optimal (70,37\%) hal tersebut disebabkan kurangnya perhatian dan pemberian pengarahan kepala ruang. Kepuasan perawat merupakan perasaan emosional yang dirasakan perawat setelah melakukan tindakan. Kepuasan perawat ini sangat dipengaruhi oleh bagaimana kepemimpinan dari kepala ruanghanya dan komunikasi dalam menyampaikan kebijakan kebawahan. Kepemimpinan efektif yang digunakan oleh kepala ruang untuk memimpin bawahannya. Komunikasi yang terjadi di dalam antara pimpinan dan bawahan itu merupakan mekanisme fundamental dalam menunjukkan kekecewaan ataupun rasa puas mereka. Jenis penelitian kuantitatif, bersifat deskriptif korelatif korelasional dan Penelitian ini menggunakan pendekatan Cross Sectional. Jumlah sampel sebanyak 61 responden yang diambil dengan menggunakan teknik Purposive Sampling. Hasil analisis menunjukkan adanya bahwa hubungan kepemimpinan efektif dan komunikasi efektif dengan kepuasan perawat dengan nilai significance sebesar $0.000<0.05$. Berdasarkan hasil penelitian, direkomendasikan perlunya pendidikan, pelatihan dan penerapan kepemimpinan efektif kepada seluruh manajer keperawatan demi terciptanya kepemimpinan efektif dan komunikasi guna meningkatkan kepuasan perawat.
\end{abstract}

Kata Kunci: Kepemimpinan Efektif, komunikasi kepemimpinan, Kepuasan Perawat

\section{ABSTRACT}

The satisfaction of nurses at Karanganyar Hospital is less than optimal (70.37\%) This is due to lack of attention and giving head of space. Nurse satisfaction is an emotional feeling that a nurse feels after action. The satisfaction of this nurse is strongly influenced by how leadership of the head only and communication in conveying the subordinate policy. Effective leadership is used by the head of space to lead his subordinates. The communication that occurred in between the leadership and the subordinate was a fundamental mechanism in demonstrating disappointment or their satisfaction. This type of quantitative study, is descriptive correlational correlative and this research uses the Cross Sectional approach. The number of samples was 61 respondents taken using the Purposive Sampling technique. The results of the analysis showed the presence of effective leadership relationship and effective communication with the satisfaction of nurses with a significance value of $0.000<0.05$. Based on the research, it is recommended the need for education, training and effective leadership implementation to all nursing managers to create effective leadership and communication to improve nurse satisfaction.

Keywords: Effective leadership, leadership communication, nurse satisfaction

\section{PENDAHULUAN}

Kepuasan perawat merupakan perasaan emosional yang dirasakakan perawat setelah melakukan tindakan dan melakukan perbandingan yang mencakup perbedaan antara harapan dan hasil yang dirasakan, apabila hasil yang dirasakan sesuai harapan maka seseorang merasa puas dan apabila hasil yang dirasakan tidak sesuai harapan maka seseorang merasa tidak puas (Qurratul A, 2013).

Hasil penyebaran angket dan observasi yang dilakukan di RSUD Karanganyar Provinsi Jawa Tengah didapatkan bahwa saat ini belum mengukur kepuasan perawat secara khusus. Studi pendahuluan terdapat 30 perawat di RSUD Karanganyar tentang kepuasan perawat didapatkan sebanyak 13 perawat $(43,8 \%)$ menyatakan puas dengan pekerjaannya dan 17 perawat $(56,2 \%)$ merasakan tidak puas dengan pekerjaannya. Angka ketidakpuasan perawat ini dapat dijadikan sebagai suatu indikator jika kondisi ini diabaikan maka diwaktu yang akan datang akan berdampak terhadap tujuan dari organisasi dalam hal ini rumah sakit. Kepuasan perawat dipengaruhi beberapa faktor yang meliputi gaji/insentif, kondisi lingkungan kerja, lingkungan sosial, keamanan, hubungan antar interpersonal, supervisi, kesempatan promosi, prosedur kerja dan kepemimpinan.

Kepemimpinan di rumah sakit sebagai manajer lini pertama menggunakan upaya upaya yang efektif sebagai salah satu kunci keberhasilan program diruang rawat (Alam, 2010). Pemimpin dapat mempengaruhi bawahannya untuk melaksanakan keinginannya 
untuk mencapai tujuan organisasi (Curtis, 2007). Kepemimpinan efektif meliputi enam komponen, yaitu pengetahuan, kesadaran diri, komunikasi, energi, tujuan dan tindakan (Swansburg, RC, 2000). Kepemimpinan efektif erat kaitannya dengan bagaimana kepala ruang menyampaikan kebijakan kepada bawahannya, sehingga seorang pemimpin diharapkan bisa dan mampu dalam berkomunikasi.

Komunikasi antara perawat dengan pasien merupakan bagian kompetensi dan pengetahuan perawat. Dengan komunikasi perawat juga dapat merencamakan intervensi dan melakukan implementasi. Komunikasi yang baik dapat meningkatkan kepuasan pasien (Wijayanto D, 2012).

Komunikasi yang terjadi di dalam antara pimpinan dan bawahan itu merupakan mekanisme fundamental dalam menunjukkan kekecewaan ataupun rasa puas mereka. Komunikasi menyatakan ungkapan emosional dari perasaan dan pemenuhan kebutuhan sosial. Dari hasi wawancara dan observasi ditemukan sering terjadi perselisihan pendapat antar perawat karena pimpinannya kurang tegas dalam komunikasi, pengambilan keputusan, dan merasa bahwa dirinya tidak diperhatikan oleh pimpinannya, perawat juga merasa kurang puas dengan tidak adanya reward yang diberikan untuk perawat yang aktif (Astuty M, 2011). Peneliti tertarik untuk melakukan penelitian tentang Analisis Hubungan Kepemimpinan Efektif Dan Komunikasi Kepemimpinan dengan Kepuasan Perawat Di Ruang Rawat Inap RS.

\section{TINJAUAN PUSTAKA}

Seorang pemimpin yang efektif adalah yang tidak hanya bekerja sendiri tanpa melibatkan siapapun. Melainkan mampu memanfaatkan berbagai potensi yang mengelilinginya. Kepemimpinan efektif bukan sekedar pusat kedudukan atau kekuatan akan tetapi merupakan interaksi aktif antar komponen yang efektif (Huber, 2006)

Berkomunikasi merupakan suatu kebutuhan hidup manusia. Dengan berkomunikasi manusia akan dapat berhubungan antara satu dengan yang lain, sehingga kehidupan manusia akan bermakna. Disisi lain ada sejumlah kebutuhan dalam diri manusia itu hanya dapat dipenuhi melalau komunikasi dengan sesama. Makin banyak manusia itu melakukan aktivitas komunikasi antara satu dengan yang lainnya, akan semakin banyak informasi yang didapatnya dan semakin besar peluang keberhasilan seseorang itu dalam kehidupannya (Mirnawati, 2014).

Kepuasan kerja merupakan wujud dari persepsi karyawan yang tercermin dalam sikap dan terfokus pada perilaku terhadap pekerjaan.Juga merupakan suatu bentuk interaksi manusia dengan Lingkungan kerjanya. Factor-faktor yang mempengaruhi kepuasan kerja adalah hubungan antar karyawan, individual, faktor luar. Kepuasan kerja dapat dipengaruhi oleh balas jasa yang adil dan layak, suasana dan lingkungan kerja yang menyenangkan, teman kerja yang menyenangkan, penempatan yang sesuai dengan keahlian, berat ringannya pekerjaan, peralatan yang menunjang, sikap pemimpin serta sifat pekerjaan yang dilakukan (Purweni, 2015)

\section{METODE}

Jenis penelitian kuantitatif, bersifat deskriptif korelatif korelasional dan Penelitian ini menggunakan pendekatan Cross Sectional. Populasi dalam penelitian ini adalah semua perawat pelaksana di Instalasi Rawat Inap sebanyak 169 perawat pelaksana di Instalasi Rawat Inap di RS. Pada penelitian ini menggunakan Teknik pengambilan sampel menggunakan Purposive Sampling yaitu teknik pengambilan sampel dengan pertimbangan tertentu. Sampel atau responden yang di ambil pada penelitian ini sejumlah 61 perawat pelaksana ruang rawat inap.

\section{HASIL DAN PEMBAHASAN}

A. Distribusi frekuensi berdasarkan

karakteristik penelitian sebagai berikut :

Tabel 1 Distribusi frekuensi karakteristik

\begin{tabular}{cccc}
\hline No & Jenis kelamin & Jumlah & Prosentase \\
\hline 1 & Laki - laki & 16 & $26.2 \%$ \\
2 & Perempuan & 45 & $73.8 \%$ \\
& TOTAL & $\mathbf{6 1}$ & $\mathbf{1 0 0 \%}$ \\
No & Usia & Jumlah & Prosentase \\
1 & $<30$ & 8 & $13.2 \%$ \\
2 & $31-40$ & 19 & $31.2 \%$ \\
3 & $41-50$ & 28 & $45.8 \%$ \\
4 & $>51$ & 6 & $9.8 \%$ \\
& TOTAL & $\mathbf{6 1}$ & $\mathbf{1 0 0 \%}$ \\
No & Pendidikan & Jumlah & Prosentase \\
1 & D3 & 1 & $1.6 \%$ \\
2 & S1 & 31 & $50.8 \%$ \\
3 & Ners & 29 & $47.5 \%$ \\
& TOTAL & $\mathbf{6 1}$ & $\mathbf{1 0 0} \%$ \\
\hline
\end{tabular}

Berdasarkan hasil 1 dapat diketahui bahwa distribusi responden menurut kelompok jenis kelamin meliputi kelompok jenis kelamin laki - laki sebanyak 16 orang (26.2\%), dan kelompok jenis kelamin perempuan sebanyak 45 orang $(73.8 \%)$.

Distribusi berdasarkan karakteristik usia meliputi pada usia $<30$ tahun sebanyak 8 orang $(13.2 \%)$, usia 31 - 40 tahun sebanyak 19 orang $(31.2 \%)$, usia $41-50$ tahun sebanyak 28 orang $(45.8 \%)$ dan usia $>51$ tahun sebanyak 6 orang 
(9.8\%). Distribusi berdasarkan karakteristik pendidikan meliputi pada pendidikan D3 sejumlah 1 orang $(1.6 \%)$, pendidikan S1 sebanyak 31 orang $(50.8 \%)$ dan yang berpendidikan Ners sebanyak 29 orang (47.5\%).

B. Hubungan kepemimpinan efektif dengan

kepuasan perawat

Tabel 2 Distribusi frekuensi kepemimpinan efektif dengan kepuasan perawat

\begin{tabular}{cccccc}
\hline Kepemimpina & \multicolumn{2}{c}{ Kepuasan perawat } & & $\mathrm{X}^{2}$ & $p$ \\
\cline { 2 - 3 } n efektif & $\mathbf{n}$ & $\mathbf{\%}$ & & \\
\hline Cukup efektif & 5 & 8.2 & & \\
Efektif & 46 & 75.4 & & \\
Sangat efektif & 10 & 16.4 & & \\
\hline Total & 61 & 100 & 49.12 & 0.00 \\
\hline
\end{tabular}

Berdasarkan table 2 di atas didapatkan hasil bahwa nilai $\mathrm{X}^{2}$ hitung sebesar 49.12 dan tingkat signifikansi ( $\alpha$ ) sebesar 0.00. Dengan demikian dapat disimpulkan bahwa terdapat hubungan yang signifikan antara kepemimpinan efektif dengan kepuasan perawat.

\section{Hubungan komunikasi kepemimpinan dengan kepuasan perawat}

Tabel 3 Distribusi frekuensi komunikasi kepemimpinan dengan kepuasan perawat

\begin{tabular}{|c|c|c|c|c|}
\hline \multirow[t]{2}{*}{$\begin{array}{c}\text { Komunikasi } \\
\text { Kepemimpinan }\end{array}$} & \multicolumn{2}{|c|}{$\begin{array}{c}\text { Kepuasan } \\
\text { perawat }\end{array}$} & \multirow[t]{2}{*}{$\mathrm{X}^{2}$} & \multirow[t]{2}{*}{$p$} \\
\hline & $n$ & $\%$ & & \\
\hline $\begin{array}{c}\text { Kurang } \\
\text { berkomunikasi }\end{array}$ & 3 & 4.9 & & \\
\hline $\begin{array}{c}\text { Baik } \\
\text { berkomunikasi }\end{array}$ & 49 & 80.3 & & \\
\hline $\begin{array}{c}\text { Sangat baik } \\
\text { berkomunikasi }\end{array}$ & 9 & 14.8 & & \\
\hline Total & 61 & 100 & 61.50 & 0.00 \\
\hline
\end{tabular}

Berdasarkan tabel 3 di atas didapatkan hasil bahwa nilai $\mathrm{X}^{2}$ hitung sebesar 61.50 dan tingkat signifikansi ( $\alpha$ ) sebesar 0.00. Dengan demikian dapat disimpulkan bahwa terdapat hubungan yang signifikan antara komunikasi kepemimpinan dengan kepuasan perawat.

D. Hubungan kepemimpinan efektif dan komunikasi kepemimpinana dengan kepuasan perawat

Tabel 4 Distribusi kepemimpinan efektif dan komunikasi

kepemimpinan dengan kepuasan

\begin{tabular}{|c|c|c|c|c|c|}
\hline \multicolumn{5}{|c|}{ perawat } & Correlations \\
\hline & Control & riables & $\begin{array}{l}\text { kep. } \\
\text { efektif }\end{array}$ & $\begin{array}{l}\text { kompimp } \\
\text { inan }\end{array}$ & $\begin{array}{c}\text { puaspe } \\
\text { rawat }\end{array}$ \\
\hline \multirow{2}{*}{$\begin{array}{c}\text {-none- } \\
\mathrm{a}\end{array}$} & \multirow{2}{*}{$\begin{array}{l}\text { kep.ef } \\
\text { ektif }\end{array}$} & Correlation & 1.000 & .582 & .462 \\
\hline & & $\begin{array}{l}\text { Significance (2- } \\
\text { tailed) }\end{array}$ & . & .000 & .000 \\
\hline
\end{tabular}

\begin{tabular}{|c|c|c|c|c|c|}
\hline & & df & 0 & 59 & 59 \\
\hline \multirow{12}{*}{$\begin{array}{l}\text { puasp } \\
\text { erawat }\end{array}$} & kompi & Correlation & .582 & 1.000 & .511 \\
\hline & $\underset{\mathrm{n}}{\mathrm{mpina}}$ & $\begin{array}{c}\text { Significance (2- } \\
\text { tailed) }\end{array}$ & .000 & . & .000 \\
\hline & & df & 59 & 0 & 59 \\
\hline & puaspe & Correlation & .462 & .511 & 1.000 \\
\hline & rawat & $\begin{array}{c}\text { Significance (2- } \\
\text { tailed) }\end{array}$ & .000 & .000 & . \\
\hline & & & 59 & 59 & 0 \\
\hline & kep.ef & Correlation & 1.000 & .454 & \\
\hline & & $\begin{array}{c}\text { Significance (2- } \\
\text { tailed) }\end{array}$ & . & .000 & \\
\hline & & $\mathrm{df}$ & 0 & 58 & \\
\hline & kompi & Correlation & .454 & 1.000 & \\
\hline & mpina & Significance (2- & .000 & . & \\
\hline & $\mathrm{n}$ & $\begin{array}{l}\text { tailed) } \\
\text { df }\end{array}$ & 58 & 0 & \\
\hline & $\begin{array}{r}\text { nntain } \mathrm{Z} \\
\text { corre }\end{array}$ & $\begin{array}{l}\text {-order (Pearson) } \\
\text { ons. }\end{array}$ & & & \\
\hline
\end{tabular}

Hasil analisis uji correlation didapatkan Nilai korelasi atau hubungan antara variabel kepemimpinan efektif dengan komunikasi kepemimpinan dalam analisis. Nilai correlation sebesar 0.582 dan nilai significance $(2$ - tailed $)$ adalah $0.000<0.05$, maka dapat disimpulkan bahwa ada hubungan yang positif dan signifikan antara kepemimpinan efektif dengan komunikasi kepemimpinan tanpa adanya variabel kontrol (kepuasan perawat). Pada tabel output kedua menunjukkan nilai korelasi hubungan antara variabel kepemimpinan efektif dengan komunikasi kepemimpinan setelah memasukkan kepuasan perawat sebagai variabel kontrol dan analisis . dari tabel diatas terlihat bahwa terjadi penurunan nilai koefisiensi korelasi menjadi 0.454 dengan nilai significance sebesar $0.000<0.05$, yang berarti bahwa hubungan kepemimpinan efektif dan komunikasi efektif dengan kepuasan perawat.

Hal ini diperkuat dengan teori Tappen (2004) yang menyatakan bahwa pemimpin harus mampu dalam berkomunikasi, berinteraksi dengan bawahannya, menerima masukan dan umpan balik dari bawahan. Penelitian lain yang sejalan dengan penelitian ini adalah penelitian Wahab (2014) yang menyatakan terdapat hubungan yang bermakna pada kepuasan kerja perawat pelaksana dengan kepemimpinan efektif kepala ruang ( $p$ value 0,000). Pelatihan kepemimpinan efektif telah memberikan arahan kepada kepala ruang untuk memberikan pengaruh, pengarahan, perencanaan, menentukan tujuan, memotivasi, berkomunikasi dan mengatur manajerial sesuai dengan tugasnya.

Penelitian ini sesuai dengan penelitian yang dilakukan Rahmayanti 2018 tentang Pengaruh Kepemimpinan Efektif terhadap Kepuasan Perawat Di Ruang Rawat Inap RSUD Karanganyar. Hasil analisis menunjukkan adanya perbedaan kepuasan perawat antara sebelum dan setelah dilakukan pelatihan kepemimpinan efektif kepala ruang ( $p$ value $=0,000)$. menyimpulkan adanya 


$\begin{array}{llr}\text { pengaruh } & \text { kepemimpinan } & \text { efektif } \\ \text { terhadap kepuasan } & \text { perawat. } \\ \text { Berdasarkan hasil } & \text { penelitian, } \\ \text { direkomendasikan } & \text { perlunya } \\ \text { pendidikan, pelatihan dan } & \text { penerapan }\end{array}$
kepemimpinan efektif kepada seluruh manajer keperawatan demi terciptanya kepemimpinan efektif guna meningkatkan kepuasan perawat (Rahmayanti N.Y., 2018).

Pendapat yang dikemukan oleh Dollan (2008) Kepemimpinan efektif merupakan kemampuan seorang pemimpin dalam memberikan keseimbangan antara pemberian tugas dan mengelola ketenagaan serta menfasilitasi pemecahan masalah dalam kesenjangan antara kemampuan, prosedur, struktur organisasi dan motivasi. Marquis \& Huston (2010) menyatakan bahwa Kepemimpinan efektif merupakan kemampuan pemimpin dalam mempengaruhi bawahan dalam pencapaian kesuksesan tujuan organisasi. Kepemimpinan efektif menuntut penguasan pemimpin akan tugas dan ketenagaan yang ada, sehingga kepuasan kerja dapat tercapai. Kepala ruang yang mempunyai kemampuan kepemimpinan efektif dan komunikasi kepemimpinan yang baik maka dapat menjadikan kepuasan staf perawat dengan nilai signifikance sebesar $0.000<0.05$.

\section{KESIMPULAN}

Berdasarkan hasil penelitian yang telah dilakukan, dapat diketahui bahwa terdapat terdapat sejumlah $46 \quad(75.4 \%)$ responden merasa kepemimpinan kepala ruang efektif, sejumlah sejumlah $49(80.3 \%)$ responden merasa pemimpinnya sudah baik dalam berkomunikasi. Analisa data menggunakan uji correlation nilai koefisiensi korelasi menjadi 0.454 dengan nilai significance sebesar $0.000<$ 0.05 , maka $\mathrm{H} 0$ ditolak dan Ha diterima yang berarti bahwa hubungan kepemimpinan efektif dan komunikasi efektif dengan kepuasan perawat

\section{SARAN}

Saran bagi rumah sakit mendukung upaya memperbaiki fungsi - fungsi manajemen keperawatan melalui penguatan kepemimpinan efektif dan melakukan pengukuran kepuasan perawat secara rutin setiap enam sekali dengan cara survei kepuasan perawat. Bagi perawat dan peneliti memicu perawat agar lebih termotivasi, bersikap terbuka dan terlibat aktif dalam kegiatan yang dilakukan oleh kepala ruang dengan harapan senantiasa untuk mendukung peningkatan profesionalisme diri dan akuntabilitas dalam bekerja.
DAFTAR PUSTAKA

Alam M, JF M. Level Of Satisfaction And Intent To Leave Among Malaysian Nurse. Bussines Intellegence Journal. 2010;3(1).

Astuty M. Pelaksanaan Fungsi Kepala Ruang Dengan Kepuasan Kerja Perawat Pelaksana Di RS Haji Jakarta. Jakarta: UI; 2011.

Curtis. Job Satisfaction : A Survey Of Nurse In The Reublic Ireland. Journal of Nursing Management. 2007(3):92-9.

Dollan, J \& Sellwood, M. How Be an Effective Leader. Friends and Earth. Issue $72 ; 2008$.

Gillies DA. Manajemen Keperawatan: Sebagai Suatu Pendekatan Sistem. Chicago: W.B Saunders Company; 2006.

Huber, D. Leadership And Nursing Care Management

ThirdEdition.Phladelphia : Saunders Elsevier.2006

Mirnawati. S, 2014, Hubungan Komunikasi Interpersonal Perawat dengan Kepuasan Pasien Rawat Inap di Ruang Cempaka RSUD AW Sjahranie Samarinda.Tidak Terbitkan

Purweni S. Perbedaan Tingkat Kepuasan dan Kinerja Perawat Terhadap Penerapan Supervisi Langsung dan Tidak Langsung di RSIA Semarang:Universitas Diponegoro; 2015.

Qurratul A,2013, Pengaruh Gaya Kepemimpinan Dan Kepuasan Kerja Terhadap Kinerja Perawat Di Ruang Rawat Inap A Rsup Dr. Soeradji Tirtonegoro Klaten

Rahmayanti N.Y, Pengaruh Kepemimpinan Efektif Terhadap Kepuasan Perawat Di RSUD Karanganyar. Semarang: Universitas Diponegoro; 2018

Swansburg RC., Swansburg RJ. Introductory Manajement and Leadership for Nurse. 2 ndedition.Toronto : Jonash and Burtlet Publisher,2000

Marquis \& Huston. Kepemimpinan Dan Manajemen Keperawatan Teori \& Aplikasi.Edisi 4, Jakarta, EGC; 2010 (45).

Tappen. Essentialof nursing leadership and management: Third edition. Philadelphia: F. A Davis Company; 2004.

Wahab, H. Hubungan antara kepemimpinan efektif kepala ruangan dengan kepuasan kerja perawat pelaksana di RSU Labuang Baji Makassar. Tesis Tidak Dipublikasikan. FIK UI; 2014.

Wijayanto D. Pengantar Manajemen. Jakarta: PT Gramedia Pustaka; 2012 